\title{
SDS-PAGE For Glutenins Protein of Some Durum Wheat Cultivars coming from Different Agro-Ecological Areas
}

\author{
Ahmed Salih Khalaf* \\ Department of Field Crops, College of Agriculture and Forestry \\ Mosul University, Mosul, Iraq
}

Received: 21 December 2005. Accepted: 13 June 2006

\begin{abstract}
Ten durum wheat cultivars of different agro-ecological resources were involved, and subjected to electrophoresis for their glutenin subunits. Glutenin subunits resolution and coding based on relative mobility. Cultivars shown differences in migration patterns and categorized into different groups in accordance to possessing a particular subunits. Caronia and Haurani were similar as they possess subunits $6+15$, while ACSAD 65, Simeto, and Waha possess subunits $7+8$; but Korifla and Gidara 2 and Creso possess subunits $6+8$ with an additional subunit 20 for the Creso. Lastly, Cham 5 and Om rabi 5 possess subunits 20.
\end{abstract}

\section{Introduction}

Durum wheat (Triticum durum Desf, $2 \mathrm{n}=28$ ) is an important cereal crops in Iraq, as it use in manufacturing of Pasta processing in addition of some traditional local food products, Bulghur Jareesh and Habia. Durum wheat classifies as a semi-arid climates crop, the Mediterranean region being the most favorite climate for growing this crop, even if the yield may be low and exposed to fluctuation up to $50 \%$ from season to another (Alsaidy, 1982). The crop is almost completely grown in the Northern regions of Iraq, particularly in the area of higher humidity (Al-Younis and Al-Shamaa, 1982, Al-Younis et al., 1987). There is an urgent need for Iraq to improve and stabilize the production of this strategic commodity (Adary et al., 2002) and to improve end-use grain quality (Abdalla et al., 1995). It has been reported by Campbell et al. (1987) high significant relationships between some measures of wheat grain quality and specific gliadin and high molecular weight glutenin subunits of hexaploid wheat. Qualitative data have confirmed the positive functional relationship between low molecular weight gutenin subunits and gluten viscoelastic properties (Im- piglia et al., 1995). Accordingly, we suggest to study and compare the glutenin subunits of some Iraqi and ICARDA durum wheat cultivars.

\section{Materials and methods}

Samples of durum wheat cultivars grown in Iraq (Caronia, Acsad-65, Simeto, and Creso) and others from ICARDA (Waha, Cham-5, Om-rabi-5, Haurani, Korifla and Gidara-2), were evaluated comparing glutenin electrophoregrams patterns. Ten grams of grain per each sample were ground using Falling number $\mathrm{AB}$, laboratory disk mill KT 30. One hundred $\mu \mathrm{l}$ of $1.5 \mathrm{M}$ dimethyl-formamide (DMF) were added to each $10 \mathrm{mg}$ of ground flour sample and stand for at least one hour with periodic shaking on Vortex, and then centrifuged at $14000 \mathrm{rpm}$ for $10 \mathrm{~min}-$ utes.

The supernatant was taken-off and the pellet was kept for glutenin electrophoresis. The procedure of Singh et al. (1991) on gradient polyacrylamide gel was adopted. One $\mathrm{ml}$ of cleaning solution $\left(50 \%\right.$ propanol $\left.^{-1}\right)$ was added and incubated at $60^{\circ} \mathrm{C}$ for 30 minutes with tenminute interval shaking. Samples were then re-

* Corresponding Author: Tel. e Fax: +964 627618461. E-mail address: asbabawat@yahoo.com. 
centrifuged for ten minutes, the supernatant was thrown and the cleaning step repeated twice and reduction by $(50 \%$ propano $1-1,80 \mathrm{mM}$ TrisHCL, pH 8.5, 2\% DTT) DL-dithiothreitol (electrophoresis reagent). $250 \mu \mathrm{l}$ of reduction solution per sample was added and incubated at $60^{\circ} \mathrm{C}$ for 30 minutes with regular shaking every ten minutes. Each sample was homogenized with Pasteur pipette to reach an optimal extraction. Thereafter were re-centrifuged for ten minutes. $200 \mu \mathrm{l}$ of the supernatant was placed in a new eppendorf tube and the rest thrown, then $2.8 \mu \mathrm{l}$ of 4-Vinylpiridine was added to each tube and incubated all at $60^{\circ} \mathrm{C}$ for 30 minutes without shaking. One $\mathrm{ml}$ of cold acetone $\left(-20^{\circ} \mathrm{C}\right)$ was added to each tube and incubated at $-20^{\circ} \mathrm{C}$ for 15 minutes (precipitation of glutenins), then centrifuged, the supernatant was thrown and the pellet was dried under fume-hood. The pellet was stored at $-20^{\circ} \mathrm{C}$ for test. The pellet was resuspended in the solution at a rate of $1 / 5(50 \mathrm{ml}$ of $0.5 \mathrm{M}$ Tris-Hcl $\mathrm{pH} 6.8,20 \mu \mathrm{l}$ of glycerol, $4 \mathrm{~g}$ of SDS, $10 \mathrm{mg}$ of bromophenol blue, the final volume should be $100 \mathrm{ml}$ ). The re-suspension was made by adding $5 \mathrm{~mL}$ of the above reported solution per each $1 \mathrm{mg}$ of weighted flour, well mixed and stored at $-20^{\circ} \mathrm{C}$. The prepared polyacrylamide gel was of $8-14 \%$ gradient. The resolving buffer consists of $3 \mathrm{M}$ Tris- $\mathrm{Hcl}$ of $\mathrm{pH} 8.8$, while running buffer consists of Tris-glycine (0.025M Tris, $0.192 \mathrm{M}$ glycine). Four $\mu \mathrm{l}$ of glutenin sample was loaded per gel slot, gel then was subjected to electrophoresis using vertical slab by Bio-Rad protean TM $11 \mathrm{US}$, at $50 \mathrm{~mA}$ and temperature $12^{\circ} \mathrm{C}$ for four hours. The gel was then fixed and stained with $150 \mathrm{ml}$ of Trichloroacetic acid $12 \%$ with $7.5 \mathrm{ml}$ Coomassie-Brilliant-blue R-250 solution (1\% in ethanol absolute) and de-stained by distilled water and photographed using Image analysis, software Bio-ID.

\section{Results and discussion}

The SDS-PAGE separates proteins bands on the basis of molecular weights and gives better and easier, with respect to clarity, resolution and interpretation. Figure 1 illustrates the patterns of glutenin subunits of the ten tested durum wheat cultivars. The bands allocated into two areas on the gel, the upper area, which represent high molecular weight glutenin subunits (HMW) and

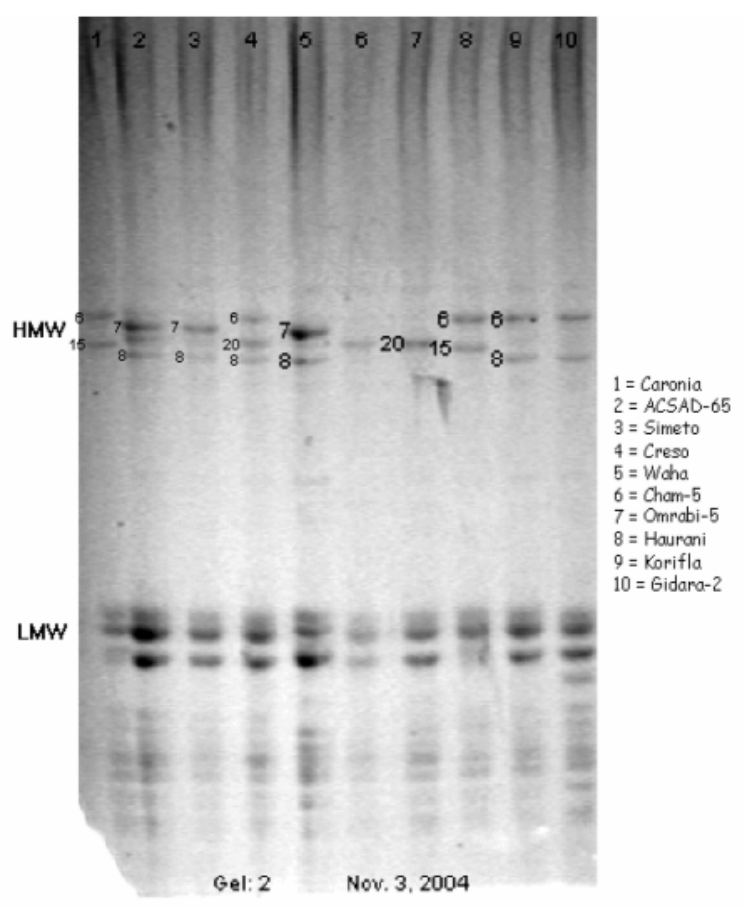

Figure 1. Electrophoretic patterns for glutenins subunits of some durum wheat cultivars of different agro-ecological resources.

the lower, which represents low molecular weight (LMW). Subunits were determined in accordance to their relative mobility $(\mathrm{Rm})$ values and numbered according to Payne and Lawrence (1983). The low molecular weight glutenin do not vary qualitatively between varieties, although there was variability in the relative band intensity. The differences were concentrated mainly in the upper area of high molecular glutenin bands. Varietal differences were verified by the presence or absence of a particular band in the electrophoregrams, these variations may be due to the genetic diversity in addition to the environmental conditions, and cultural practices (e.g. cropping systems, previous crop in rotation, fertilization and annual rainfall). Cseus et al., 2002, reported that especially the rains had a strong effect on the quality of durum wheat and on grain characters such as yellow pigments and gluten extensibility. Cultivars were classified into different categories according to the presence of bands (Tab. 1). Among the tested cultivars, the Iraqi Caronia and the Syrian Haurani seems to be very close, as both possess the two bands 6 and 15; this was 
Table 1. Categorizing ten durum wheat cultivars in accordance to the HMW glutenin subunits.

\begin{tabular}{lc}
\hline $\begin{array}{l}\text { Durum } \\
\text { Cultivars }\end{array}$ & $\begin{array}{c}\text { Subunits of } \\
\text { HMW glutenin }\end{array}$ \\
\hline 1-Caronia & $6+15$ \\
2-ACSAD 65 & $7+8$ \\
3-Simeto & $7+8$ \\
4-Creso & $20 / 6+8$ \\
5-Waha & $7+8$ \\
6-Cham 5 & 20 \\
7-Om rabi 5 & 20 \\
8-Haurani & $6+15$ \\
9-Korifla & $6+8$ \\
10-Gidara & $6+8$ \\
\hline
\end{tabular}

also confirmed by Khalaf et al., 2005, based on phenol reaction test, as both gave positive reactions which was attributed to the tyrosinase (monophenolase) enzyme activity (Csala, 1972). Cultivars ACSAD 65, Simeto, Waha, Korifla, and Gidara 2, were similar in having bands 7 and 8 . While on the other hand, Korifla, Gidara 2 and Creso possess bands 6 and 8 in addition to 20 for Creso. Lastly, Cham 5 and Om rabi 5 possess band 20. The migration pattern of HMW glutenin subunits of the cultivar Creso is similar to that reported by Ciaffi et al. (1993) in possessing bands 6 and 8 .

\section{Acknowledgements}

The author wishes to express his sincere gratitude and appreciation to Dr. Miloudi Nachit and to all durum quality assessment technical staff at ICARDA, Syria, Aleppo, for their assistance to accomplish this work.

\section{References}

Abdalla O.S., Pena R.J., Autrique J.E., Nachit M.M. 1995. Durum wheat breeding and quality improvement at CIMMYT Mexico. In: Di Fonzo N., Kaan F., Nachit M.M. (eds.): Durum wheat quality in the Mediterranean region. Ciheam.

Adary A., Hachum A., Oweis T., Pala M. 2002. Wheat productivity under supplemental irrigation in North- ern Iraq. ICARDA. On-Farm water husbandry research report series, No. 2.

Al-Ansary M.M. 1982. Production of field crops. Mosul University Press. (in Arabic).

Al-Saidy M.A. 1983. Cereal technology. (Mosul University Press). (in Arabic).

Al-Younis A., Mohammed A., Elias Z.A. 1987. Cereal crops. Mosul University Press. (in Arabic).

Al-Younis A.A., Al-Shamaa W.S. 1982. Cereals and legumes crops. Printed in France by SIMA-ROTOMAG.77200 TORCY (6) 006.33.63. In Arabic.

Campbell W.P., Wrigley C.W., Cressey P.J., Slack C.R. 1987. Statistical correlations between quality attributes and grain-protein composition for 71 hexaploid wheats used as breeding parents. Cereal Chemistry, 64:293-299.

Ciaffi M., Lafiandra D., Porceddu E., Benedettelli S. 1993. Storage-protein variation in wild emmer wheat (Triticum turgidum ssp. dicoccoides) from Jordan and Turkey. 1. Electrophoretic characterization of genotypes. Theor App. Genet., 86:474-480.

Csala M.V. 1972. The methodology and mechanism of the phenol reaction in cereals. Proc. Int. Seed Test. Ass. 37:915.

Cseus L., Matuz J., Beke B. 2000. Annual effect on grain quality of winter wheat (Triticum turgidum L. var. durum) in Szeged, Hungary. In: Royo C., Nachit M.M., Di Fonzo N., Araus J.L. (eds.): Proceedings of the seminars jointly organized by Ciheam (International Center for advanced Mediterranean agronomic studies).

Impiglia A., Nachit M.M., Lafiandra D., Porceddu E. 1995. Effect of gliadin and glutenin components on gluten strength in durum wheat. In: Di Fonzo N., Kaan F., Nachit M.M. (eds.): Durum wheat quality in the Mediterranean region. Ciheam.

Khalaf A.S, Nachit M., Hassan A.I., El-Saleh A. 2005. Evaluation of grain quality properties of some Iraqi and ICARDA selected durum wheat cultivars. Accepted for publication in Mesopotamia J. of Agric., 33:13-21.

Payne P.I., Lawrence G.J. 1983. Catalogue of alleles for the complex gene loci, Glu.A1,Glu-B1 and Glu-D1 which code for high molecular weight subunits of glutenin in hexaploid wheat. Cereal Res. Commun., 11:29-35.

Singh N.K,. Shepherd K.W., Cornish G.B. 1991. A simplified SDS-PAGE procedure for separating LMW subunits of glutenin. J. Cereal Sci., 14:203-208. 